日耳鼻 100：1394 -1400，1997

大本本和也

毛利 光宏

天津 睦郎

寺岡 優*

神戸大学医学部

耳鼻咽喉科学教室

*加西市民病院耳鼻咽喉科

\section{気管外膜, 軟骨膜および輪状靯帯の組織学的研究} 一正常構造の検討一

気管は輪状軟骨下端からはじまり，下方では左右の主気管支に分岐する．気管 浸潤は甲状腺癌, 下咽頭癌, 食道癌などで予後を左右する重要な因子の一つであ り，これらの浸潤様式を知るには，気管の正常構造に関する明確な知識が必要で ある。

この研究は気管の正常構造を明らかにするために行った. 5 例の摘出標本から 腫瘍浸潤がない部分の気管を切り出し, 組織学的および免疫組織化学的に検討し た。

従来より外膜と呼ばれている気管をとりまく疎な結合組織は，へマトキシリン エオジン染色で外側の疎な層と内側の密な層の 2 層に分かれていた。この層構造 は輪状靱带に近い部位では明瞭であったが，離れた部位では明瞭ではなかった。 内側層の結合組織は, 斜めに走行し輪状靱帯に移行した後粘膜下層に達していた. このような構造は気管の伸展性と屈曲性に奇与すると考えられた。

気管軟骨は軟骨膜で被われている.HE染色では, 表層の線維芽細胞と成熟した 軟骨細胞との間に楕円形あるいは紡鍾形の細胞からなる未成熟な軟骨細胞の層が 認められた。この層はエラスチカ・ワン・ギーソン染色で赤色に染色され, 周囲 との境界は明瞭であった，免疫組織化学的検討では，表層の線維芽細胞と末成熟 な軟骨細胞の層にはコラーゲンI およびIII型の広範な分布が認められた。しかし 成熟した軟骨細胞の層にはほとんど認められなかった．これらのことから未成熟 な靯骨細胞の層は軟骨膜に含まれるのが妥当であると考えた.

結論は以下のごとくであった．1．気管外膜は,外側の疎な線維組織からなる層 と内側の密な層の 2 層に分類された。 2. 軟骨膜は,外側の線維層と内側の移行層 の 2 層に分類された. 3. 外膜内側層の線維束は輪状靶帯に移行し,気管の伸展性 と屈曲性に寄与すると考えられた。

$$
\text { キーワード : 気管外膜, 軟骨膜, 輪状靭带, コラーゲン, 組織学 }
$$

はじめに

気管は軟骨部と膜様部からなる管で，中枢側は輸状軟 骨につながり，末梢側は気管分岐部で左右の主気管支に 分かれる.耳鼻咽喉科領域で気管に浸潤する腫瘍として は, 甲状腺癌をはじめ下咽頭癌, 食道癌, 啹頭癌および それらのリンパ節転移などがある.かつては気道の再建 が容易ではないために，これらの腫瘍の気管浸潤例に対 し気管合併切除はあまり行われなかったが1)，近年では 積極的に気管を合併切除することにより，良好な成績が 得られるようになっている2)，しかもこれらの腫瘍に おいては気管浸潤の有無とその程度が予後に影響を与え
る因子の一つであることが報告されている がって, 腫瘍の気管への浸潤様式を知ることは治療を行 う上で重要なことと考えられる。

気管は, 外側より外膜, 軟骨膜, 軟骨, 粘膜の構造を 有する(図 1)，気管に関する組織学的研究は粘膜に関す るものが多いのに対し, 外膜, 軟骨膜や輪状鞄带等の支 持組織についての研究は比較的少ない ${ }^{17) ~ 20)}$.これらのう ち軟骨膜の構造については軟骨層との境界に関していま だ定説がなく(1819921) 299，さらに外膜の構造については， 我々が涉猟した限りこれを詳細に検討した報告はみられ ない. 腫場の気管浸潤様式を知るためには，まずこれら 


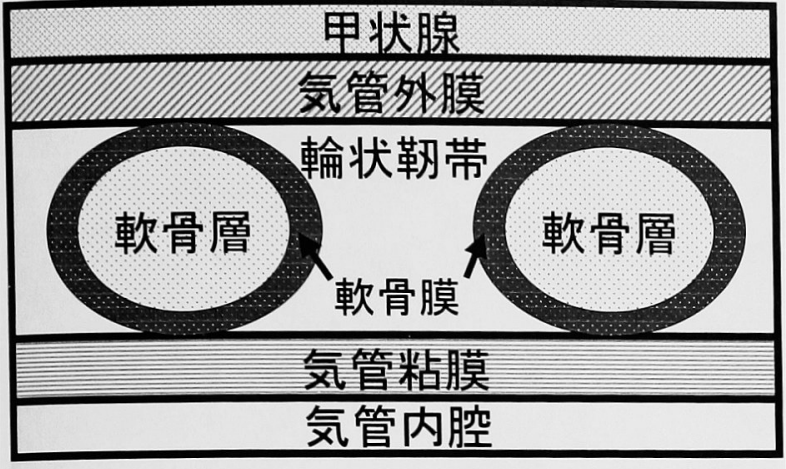

図 1 気管縦断面の模式図

気管外膜, 軟骨膜, 輪状䩸帯の組織学的構造を明確にす ることが必要であると思われる。そこで摘出標本をもと に,これらの正常組織像について検討した。

また近年，腫瘍浸潤に対する細胞外マトリックスの役 割が注目されている．その1つであるコラーゲンは生体 内に広く分布し,気管においても主要な構成成分である。 腫瘍が気管軟骨に浸潤する際にはまず気管軟骨膜に接す ることになる，身体他部位の軟骨膜には I 型およびIII型 コラーゲンの存在が報告されている(30131) が，気管軟骨膜 に関する報告はみられない。そここで今回この気管軟骨膜 におけるI 型抢よびIII型コラーゲンの局在についても免 疫組織化学的に検討した。

\section{材料と方法}

\section{1. 材料}

喉頭または下咽頭癌で気管と甲状腺の合併切除を行っ た 5 症例の摘出標本から, 正常気管とその上方で甲状腺 が付着している部分の気管を甲状腺が剥がれないように 切り出し材料とした。

\section{2. 方法}

材料を横断面および綐断面で切り出し，10\%緩衝フォ ルマリン液で固定した。必要に応じて $10 \%$ EDTA で脱灰 した.これらをパラフィン包埋し $4 \mu \mathrm{m}$ の厚さの薄切標 本を作製した。また 10 枚ごとに厚さ $8 \mu \mathrm{m}$ の切片を作製 した. 薄切標本に対し，型のごとくへマトキシリン・エ オジン染色 (以下, HE 染色), エラスチカ・ワンギーソ ン染色 (以下, EV 染色) および鍍銀染色 (渡辺法) ${ }^{32)}$ 行い, 膠原線維, 弾性線維, 細網線維を染色した。

免疫組織化学的検索は, Shandon-Lipshaw 社の Omnitages Plus キットを使用し avidin-biotin-affinity 法 により行った。前処置として $0.1 \%$ ペプシン溶液に $37^{\circ} \mathrm{C}$, 2 時間反応させた. 脱パラフィン後, $3 \% \mathrm{H}_{2} \mathrm{O}_{2}$ 液に 30 分 浸透させ内因性ペルオキシダーゼを除去した後, phosphate buffered saline (PBS) で洗浄してブロッキング を行った。抗 I 型コラーゲン抗体（ポリクロナール，カ
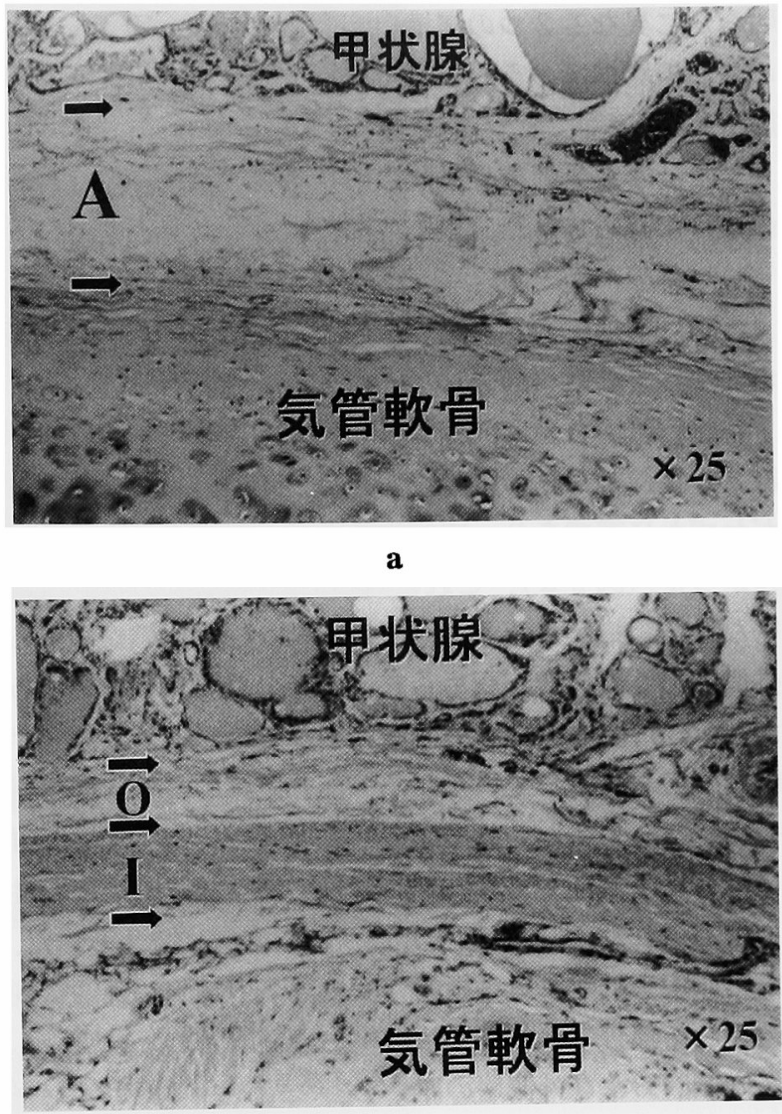

b

図 2 気管外膜の組織像 (HE)

$\mathrm{a}$ ：輪状勒帯から遠い部位 外膜の層構造は明らかではない．

$\mathrm{b}$ ：輪状勒帯に近い部位

内側層と外側層の違いが明瞭である.

$\mathrm{A}$ ：外膜， I：内側層, $\mathrm{O}$ : 外側層

ルテット社）および抗II型コラーゲン抗体（同上）を一 次抗体として, $4^{\circ} \mathrm{C} て ゙ 24$ 時間反応させた. PBS で洗浄後, 二次抗体と 30 分間反応させた. PBS で洗浄後, ペルオキ シダーゼ標識ストレプトアビジンと 30 分間反応させた. さらに diaminobenzidine で発色させ, PBS で反応停止 後,ヘマトキシリンで核染色を行い光学顕微鏡下に観察 した。陽性コントロールには皮膚抢よび動脈を用い，陰 性コントロールには一次抗体の代わりに正常ウサギ血清 を用いて比較検討した。

$$
\text { 結果 }
$$

1. 組織学的所見

甲状腺被膜と気管軟骨膜の間には，主に柾な線維組織 からなる平均幅 $0.45 \mathrm{~mm}$ の外膜が認められた。気管軟骨 の表層には染色性と細胞形態からみて軟骨層（C）とは 


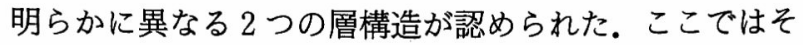
の 2 つの層構造のうち表層で線維成分に富むものを線維 層 $(\mathrm{F})$, 深層で軟骨層に移行している層を移行層 $(\mathrm{T})$ とした。また気管軟骨輪間の輪状勒帯では特徴的な線維 の走行が認められた. 以下各部位について詳述する.

1) 外膜

外膜は輪状靯帯から遠い部分と, 近い部分とでは構造 が異なっていた（図 2 ).

輪状靱帯から遠い部分では，比較的均一で柾な膠原線 維と弾性線維が気管軟骨輪と平行に走行していた。 外側 がわずかに密であり, 内側より血管が豊富で弾力線維が 多かった（図 $2 \mathrm{a}$ ).これに対して輪状勒帯の近傍では, 密な線維組織からなる内側層と, 疎な線維組織からなる 外側層の 2 層構造が認められ, 両者の境界は明瞭であっ た(図 2 b). また外膜内側層の密な線維組織は大部分が 輪状靱帯に移行していたが, 一部は気管の長軸方向と平 行に走行していた．外側層では，血管が豊富で膠原線維 の走行は不規則であり, かつ少量の弾性線維がびまん性 に認められた。細網線維は外側及び内側層に認められた。 また原疾患に対する手術操作で気管と甲状腺が鈍的に剥 離された部分では外膜のほほ中央で剥離されていた。

内側層および外側層の厚さを各々 20 所で測定した平 均値は各々 $0.22,0.23 \mathrm{~mm}$ であり, ほほ同じ厚さであっ た。

\section{2) 軟骨膜}

（1）線維層

気管軟骨の最も表層にある線維層は, $\mathrm{HE}$ 染色では線 維芽細胞に類似した細胞が認められ，線維成分が豊富で 強い好酸性が認められた。外膜及び移行層との境界は明 瞭であった (図 $3 \mathrm{a}$ ). EV 染色ではこの層は黄赤色に染 色され，膠原線維とわずかな弾性線維が認められた (図 3 b). 鍍銀染色では, 細網線維は認められなかった (図 $3 \mathrm{c}$ ).

\section{(2) 移行層}

線維層の内側の移行層は, HE 染色では楕円形または 紡鍾形の未分化な軟骨細胞が，線維層に平行に配列した 層として認められた。これらの軟骨細胞は, 外側の線維 層に近いほど未分化で，軟骨層に近いほど成熟した傾向 を認めたが, 移行層と軟骨層との境界では成熟段階に大 きな変化があり, 層の違いが明瞭に認められた. 一方, 染色性の点から両層境界部を検討すると, $\mathrm{HE}$ 染色では 軟骨層の好塩基性が移行層に近づくにしたがって弱くな る傾向を認め, 両者の境界は明瞭でなかった（図 3 a). しかし EV 染色では, 境界は比較的明瞭であった.すな わち, 軟骨層は黒紫色に染色されたのに対し, 移行層は 弾性線維が認められず, 膠原線維が豊富で赤色に染色さ

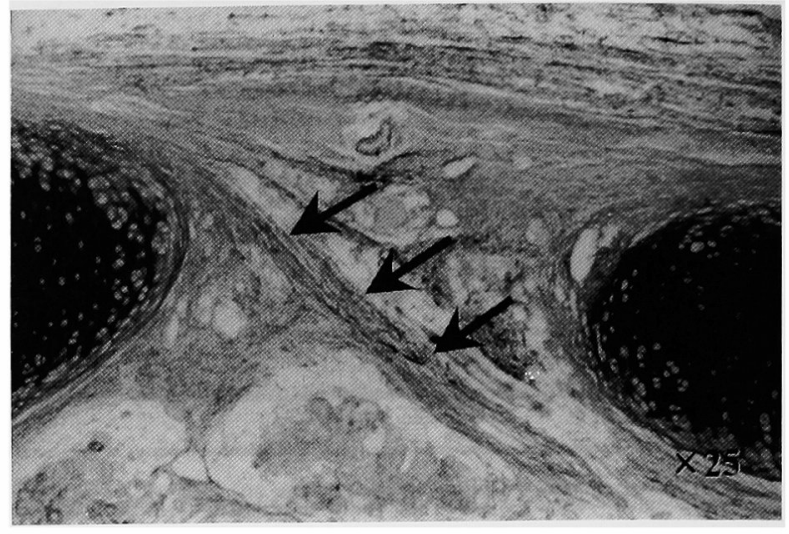

a

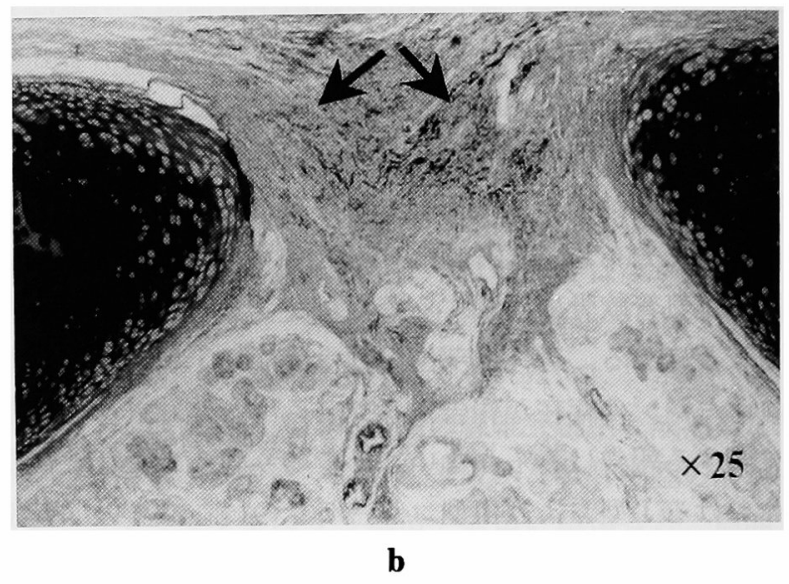

図 4 輪状靯帯の組織像（EV）

$\mathrm{a}$ ：外膜内側層からの密な線維組織が対側 の粘膜下組織に移行するように斜行してい る $(\rightarrow)$. $\mathrm{b}$ : 一部では隣接する上下の外膜内側層か らの線維組織が交差している $(\rightarrow)$.

れた(図 3 b). 鍍銀法では細網線維は認められなかった (図 $3 \mathrm{c}$ ).

甲状腺側の線維層と移行層の厚さを各々20力所で測定 した平均値は各々 $2.80,3.45$ cell layers であり, 気管粘 膜側の厚さを同様に測定した結果が各々 $2.15,2.95$ cell layersであったのに比べるとより厚い傾向があった.こ こでは厚さを細胞が平均何層であるかで表した。

3）輪状䩗帯

多くの輪状勒帯では，外膜内側層から移行した密な弾 性線維が隣接する気管輪の粘膜下組織に移行するように 走行していた(図 $4 \mathrm{a})$ ）この線維以外の部位では比較的 疎な結合組織からなっていた。一部の輪状靶帯では隣接 する上下の軟骨輪の外膜内側層から気管粘膜下組織に向 かってのびる線維束が交叉して密な線維組織が認められ た (図 4 b). 


\section{大 木 本 論 文 付図}

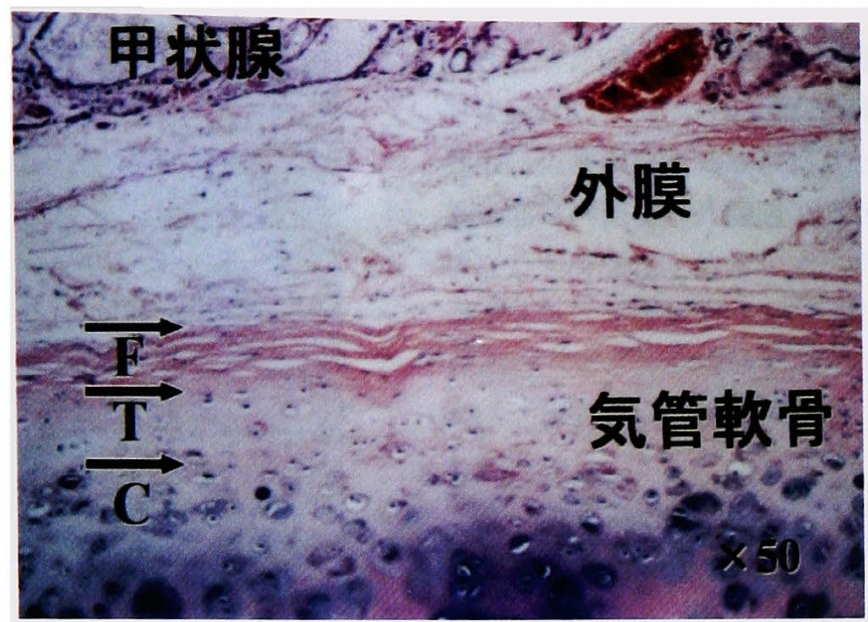

a : HE 染色

層構造の境界は明瞭ではない。

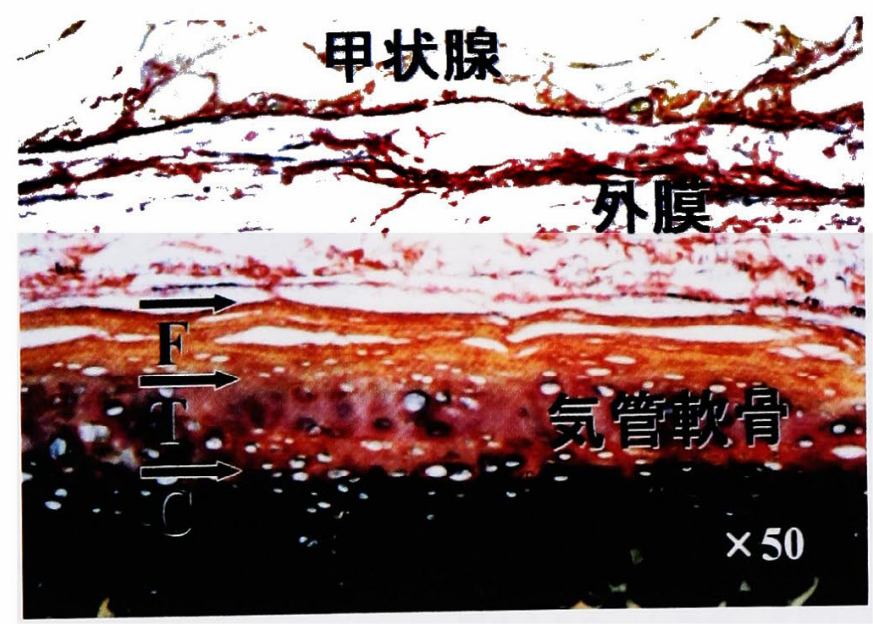

b：EV 染色

$\mathrm{HE}$ 染色より境界は明瞭である.

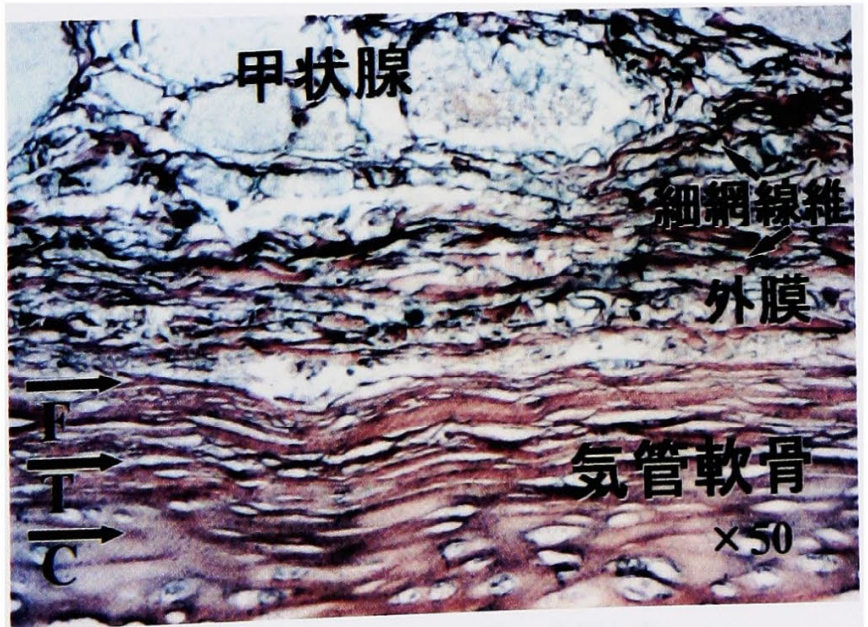

c：Ag染色

線維層および移行層には, 細網線維 $(\rightarrow)$ は

認められない。

$\mathrm{F}$ ：線維層， $\mathrm{T}$ ：移行層, $\mathrm{C}$ ：軟骨層.

図 3 気管軟骨膜の組織像 


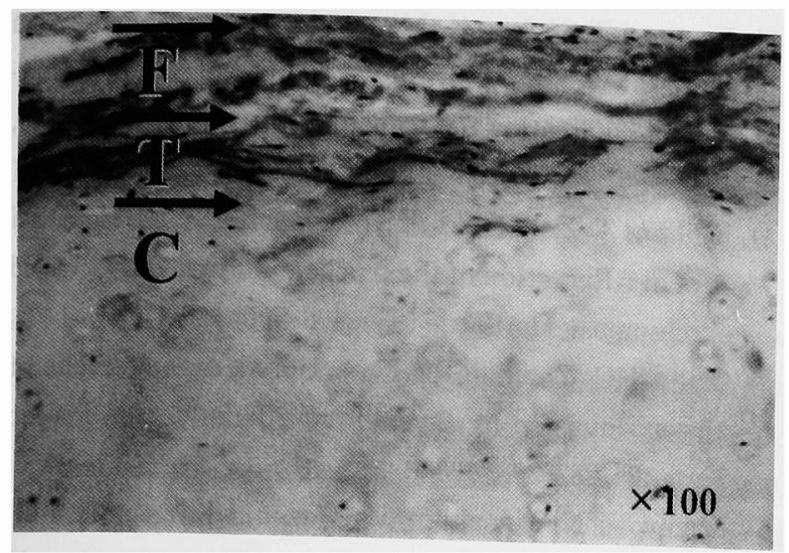

a

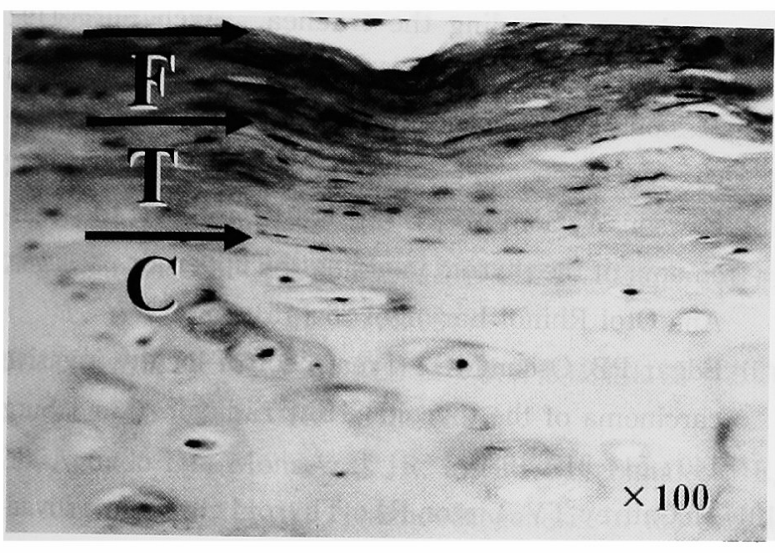

b

図 5 抗コラーゲン I 型 (a)および III 型 (b) 抗体 を用いた免疫組織化学染色

I 型, III 型ともに軟骨膜に広範な陽性像を 認める. III 型では移行層より線維層で反応 が強い.軟骨層では陽性像は認められない.

\section{2. 免疫組織化学的所見}

抗 I 型コラーゲン抗体を用いた免疫染色では, 線維層, 移行層共に線状の陽性像を認めた(図 5 a). 帯および外膜にも広い範囲で陽性像が認められた。

抗III型コラーゲン抗体を用いた免疫染色においても広 い範囲に陽性像が認められた。しかし，I 型コラーゲン とは異なり, その陽性像は, 線維層, 移行層共に一様な 分布であり，線維層では移行層より強い反応が認められ た(図 5 b). 軟骨層には I 型及びIII型コラーゲンともに 陽性像は認められなかった。

\section{考察}

気管軟骨膜と甲状腺の間の結合組織は一般に外膜と呼 ばれる17)33). 外膜については, 前述のように輪状勒帯の近 傍では線維の密な内側層と疎な外側層の 2 層構造が認め られた。輪状䨣帯から遠い部位では疎な結合組織が一様
に存在するのみで明瞭な 2 層構造を認めなかった. しか し手術時に気管から甲状腺が鈍的に剝離された部分で, 外膜のほほ中央で剝離されたという結果から, この際の 剥離面は内側層と外側層の境界とみてよいと思われる. すなわち外膜は全体として, 内側層と外側層の 2 層構造 をなすものと考えられた。気管と甲状腺を鈍的に剥離し た場合，ここでいう外側層は甲状腺側に含まれることか ら，この外側層は気管の一部とは考えにくいように思わ れた。

軟骨膜の構造については，先に述べたように軟骨層と の境界をめぐって，すなわちここで言う移行層を軟骨膜 に含めるか否かでいまだ定説がない.軟骨膜の層構造は, 1 層とするものから 3 層とするものまでの報告がみられ る18)19)21) 29).

気管軟骨の最も表層にある線維層は，HE 染色および $\mathrm{EV}$ 染色標本のどちらにおいても周囲との境界は明瞭で あった．線維層を軟骨膜と考えるのは諸家の一致した意 見であり，1層とするものはこの線維層のみを軟骨膜と している18)21)22).

しかし移行層が軟骨膜に含まれるかどうか，あるいは 移行層が 1 層であるか 2 層であるかという点では意見が 分かれている．線維層の内側にある移行層は未分化な軟 骨細胞からなる. HE 染色では軟骨層と移行層の境界は 明瞭ではないが，EV 染色においては両者の染色性が異 なり，境界が明瞭であった。また両者の構成細胞は形態 学的にも内側の軟骨層の細胞とは明らかに大きな違いが 認められた。したがって移行層は軟骨層とは異なる 1 つ の層としてみることができると考えた。

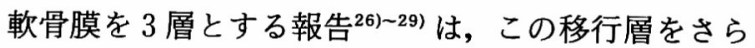
に細胞形態の違いから 2 層に分ける考え方であるが，今 回の検討では移行層を 2 層に分けるべき細胞形態の違い は見出しえなかった。

また免疫組織化学的検討では, 軟骨層には I 型および III型コラーゲンの分布は認められなかったが, 線維層お よび移行層には両方とも豊富に分布していた. したがっ てコラーゲンの分布からは移行層は軟骨層と異なり, 線 維層と同じと言える.また臨床上, 軟骨膜を軟骨から鋭 的に薄利した場合移行層が様々な厚さで剥離されるとさ れる ${ }^{24)}$. 以上のことからも移行層は線維層と同様に軟骨 膜に含めるのが妥当であると考えた。このように我々は 気管軟骨膜の組織像を, 外層の線維層と内層の移行層の 2 層に分類した。

次に軟骨膜の厚さについては, 石川ら ${ }^{24)}$ は耳介軟骨の 報告で凹面と凸面とを比較し, 凸面の方が厚い傾向が あったと報告している.今回の気管軟骨においても同様 の結果であり, 凹面の粘膜側より凸側の甲状腺側の方が 
厚い傾向にあった。

輪状靶帯における線維組織の方向性は非常に特幑が

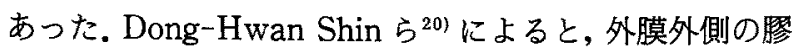
原線維は気管壁と平行に走り，内側の線維は輪状靶帯に 向かい気管内腔と垂直に走行するとしている。しかし今 回の検討では，外膜内側層からの線維は軟骨輪間を斜め に走行しているものが多かった，気管の上方には喉頭が あり，下方には気管支がある。喉頭および気管支は呼吸， 発声，噯下，咳嗽の際に動くので，これらを結ぶ気管に はある程度の伸展性が要求される.また頭部の動きに伴 う届曲性も必要である.この線維の特殊な方向性は気管 に十分な伸展性と屈曲性を持たせうると考えられ，きわ めて合目的な構造と思われた。 またこの特徴的な線維の 走向は同時に腫惶の気管浸潤様式にも大きく影響するも のと考えられる.

コラーゲンは現在までに19種のタイプが報告されてお り，生体㔻白質の約 3 分の 1 を占める主要な構成成分で ある. 今回の検討でI 型および山型コラーゲンは, 線維 層および移行層に広く分布することがわかった。これら の産生部位については，前駆体である procollagen が軟 骨膜に認められるとする報告 ${ }^{30131)}$ がある．細網線維は軟 骨膜にはほとんど認められず外膜には豊富に存在してお り,外膜でのコラーゲンIII型の分布とよく一致していた。 これは細網線維がコラーゲンIII型を主体とした微細な翏 原線維であるとする報告 ${ }^{17)}$ に合致する結果であった。

\section{結 論}

気管外膜，軟骨膜および輪状靶帯について正常組織像 を検討し，以下の結論を得た。

1. 外膜は内側層と外側層の 2 層に分類された。

2. 軟骨膜は, 線維層と移行層の 2 層に分類するのが 妥当であると考えられた。

3. 輪状靱帯では膠原線維むるよび弾性線維が斜めに走 行する特徴的な構造が認められ, 気管の伸展性, 屈曲性 に寄与していると考えられた。

4. I 型およびIII型コラーゲンは軟骨膜線維層と移行 層共に広く分布していた．III型コラーゲンは移行層より 線維層に強い局在を認めた。

\section{参考文献}

1) Hirabayashi RN, Lindsay $S$ : Carcinoma of the thyroid gland: statistical study of 390 patients. J Clin Endocrinol 21: 1596-1601, 1961.

2) Ishihara $T$, Kikuchi K, Ikeda $T$, Inoue H, Fukai S, et al: Resection of thyroid carcinoma infiltrating the trachea. Thorax 33: 378-386, 1978.
3) Tsumori T, Nakao K, Miyata M, Izukara M, Monden $\mathrm{Y}$, et al : Clinicopathologic study of thyroid carcinoma infiltrating the trachea. Cancer $56: 2843-2848$, 1985.

4) Ishihara $T$, Yamazaki S, Kobayashi $K$, Inoue H, Fukai $\mathrm{S}$, et al : Resection of the trachea infiltrated by thyroid carcinoma. Ann Surg 195: 496-500, 1982.

5) Grillo HC, Zannini P: Resectional management of airway invasion by thyroid carcinoma. Ann Thorac Surg 42 : 287-298, 1986.

6) Kazuyasu N, Masahiko M, Masaaki I, Yasumasa M, Masazumi $M$ et al: Radical operation for thyroid carcinoma invading the trachea. Arch Surg 119: 1046-1049, 1984.

7) Sessions-DG : Recent advances in surgery of the larynx and trachea. Head-Neck-Surg 5: 42-52, 1982.

8) Lawson W, Som ML, Biller HF : Papillary adenocarcinoma of the thyroid invading the upper air passages. Ann Otol Rhinol Laryngol 86: 751-755, 1977.

9) Edgar PB, Oscar MG: Treatment of locally invasive carcinoma of the thyroid: How radical? Am J Surg $140: 514-517,1980$.

10) McCaffrey TV, Lipton RJ : Thyroid carcinoma invading the upper aerodigestive system. Laryngoscope $100: 824-830,1990$.

11) Silliphant WM, Klingk GH, Levitin MS: Thyroid carcinoma and death: A clinicopathological study of 193 autopsies. Cancer 17 : 513-525, 1964.

12) Tytor $\mathrm{M}$, Olofsson $\mathrm{J}$ : Thyroid tumors invading the larynx and trachea. J Otolaryngol 15: 74-79, 1986.

13) Nomori $H$, Kobayashi $K$, Ishihara $T$ Torikata $C$, Hosoda $\mathrm{Y}$, et al: Thyroid carcinoma infiltrating the trachea : clinical, histologic and morphometric analyses. J Surg oncol $44: 78-83,1990$.

14) Rockley-TJ, Powell-J, Robin-PE ; Reid-AP : Postlaryngectomy stomal recurrence: tumour implantation or paratracheal lymphatic metastasis? ClinOtolaryngol 16: 43-47, 1991.

15) Olofsson J, Nostrand AWP: Growth and spread of laryngeal and hypopharyngeal carcinoma with reflections on the effect of preoperative irradiation: 139 cases studied by whole organ serial sectioning. Acta Otolaryngol Suppl 308 : 1-84, 1973.

16）天満和男, 阿保七三朗, 北村道彦, 橋本正治, 泉 啓 一, 他：食道癌再発転移様式に関する考察 一術後再発 剖検例の検討一。胸外会誌 $42: 2193-2199,1994$.

17）小野 譲: 気管食道科学 日本気管食道科学会編. 医学 書院: 21-28頁, 1968. 
18) Junqueira LC, Carneiro J, Contopoulos AN : Cartilage. Basic histology (2nd Ed), Lange Medical Publications: pp 111-118, 1977.

19) Williams PW, Warwick R: Osteology. Gray's Anatomy (36th Ed), ed. by Gray. Churchill Livingstone: pp 245-252, 1980.

20) Dong-Hwan shin, Engene JM, Hon Chi Suen, Hermes CG : Pathologic staging of papillary carcinoma of the thyroid with airway invasion based on the anatomic manner of extension to the trachea: A clinicopathologic study based on 22 patients who underwent thyroidectomy and airway resection. Hum Pathol 24 : $866-870,1993$.

21）溝口史郎：図説組織学（第 1 版）. 金原出版：57-73頁, 1983.

22) 藤田尚男, 藤田恒夫: 標準組織学総論 第 2 版. 医学書 院：141-145頁, 1981 .

23）廣瀨勇：ウサギ軟骨膜の自家移植実験における軟骨形 成. 歯科学報84: 81-107, 1984.

24）石川浩三, 一色信彦: 軟骨膜の軟骨形成能に関する研 究. 日形会誌 $8 ： 419-434,1988$.

25) Aguado DL, Monserrat JR, Pinero BP, Banales ME, Gutierrez R, et al: Neochondrogenesis in the septal area after submucous cartilaginous resection. Acta Otolaryngol 112 : 539-544, 1992.

26）高户 毅, 波利井清紀，中塚貴志: 軟骨膜の軟骨形成能 に関する研究 一第 1 報: 家鬼耳介軟骨膜を用いた実験 一。形会誌 $6: 14-22,1986$.

27) Engvist O. Skoog V, pastacaldi P, Yormuk E, Juhlin $\mathrm{R}$ : The cartilaginous potential of the perichondrium in rabbit ear and rib: A comparative study in vivo and in vitro. Scand J Reconstr Surg 13:275-280, 1979.

28) Engkvist $O$ : Reconstruction of patellar articular car tilage with free autologous perichondrial grafts. Scand J Plast Reconstr Surg 13: 361-369, 1979.

29) Ohlsen L, Widenfalk B: The early development of articular cartilage after perichondrial grafting. Scand J Plast Reconstr Surg 17 : 163-177, 1983.

30) Dominique LG, Frederic MG, Isabelle $T$, Jacky $B$, Pascale $\mathrm{P}$ et al : Localization of the expression of type I, II and III collagen genes in human normal and hypochondrogenesis cartilage canals. Histochemical J 26: 695-704, 1994.

31) Hamada K, Okawara $Y$, Fryer JN, Tomonaga A, Fukuda $\mathrm{H}$, et al: The detection of the mRNAs of procollagen types I, II and III in human fetal fingers by in situ hybridization using digoxigenin-labelled oligonucleotide probes. Hisochem J 27 : 309-317, 1995.

32）渡辺恒彦：常用染色法としての鍍銀法と脂肪染色につい て. 臨床病理 特 9:80-85, 1959 .

33）小川和朗，溝口史郎：組織学 第 2 版。分光堂：68頁， 1993.

本論文の要旨の一部は, 第97回日本耳悬咽侯科学会総会(福 岡)ならびに第20回日本頭頸部腫瘍学会 (福井)においてロ演 した.

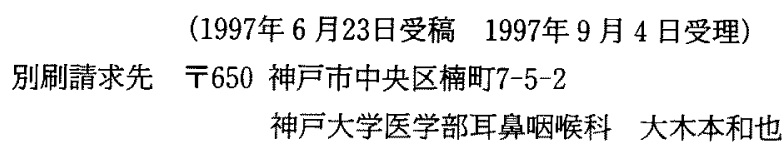

Histological Study of the Tracheal Adventitia, Perichondrium and Annular Ligament

Kazuya Ohkimoto, M.D., Mitsuhiro Mouri, M.D., Mutsuo Amatsu, M.D. and Masaru Teraoka, M.D.*

Department of Otolaryngology-Head and Neck Surgery, Kobe University, School of Medicine, Kobe ${ }^{*}$ Department of Otolaryngology, Kasai Municipal Hospital, Hyogo

The trachea begins at the lower border of the cricoid cartilage and passes down to bifurcate into the left and right mainstem bronchi. The presence of tracheal invasion is crucial factor influencing the prognosis for patients with cancers of the thyroid gland, hypopharynx, esophagus, etc. In order to understand the manner of invasion of the above tumors, precise knowledge of the normal tracheal structure is indispensable. This study was undertaken to clarify the normal microscopic structure of the trachea. Five normal tracheal specimens obtained at surgery were examined histologically and immunohistochemically. The loose connective tissue around the trachea, known as adventitia, was divided into a loose outer and a dense inner layer by hematoxylin and eosin (HE) staining. This two-layer pattern was clearly seen near the annular ligament but was obscured away from it. The connective 
tissue of the inner layer ran obliquely to join the connective tissue of the annular ligament and ended in the submucosal layer. This arrangement of connective fibers seems to play a role in allowing the trachea to stretch and bend. Tracheal cartilage is covered with a dense fibrous membrane known as the perichoundrium. Between the superficial fibrous membrane and mature cartilage cells lies zone of immature cartilage made up of oval or spindle cells, and the inclusion of this zone in the perichondrium has long been a subject of controversy. In our study, the zone was homogeneously stained red by the elastica van Gieson's stain and was clearly distinguished from other structures. Immunohistochemical staining revealed a wide distribution of type I and type III collagen on the fibrous membrane and the zone of immature cartilage cells, while mature cartilage cells did not show such collagen. Based on these findings, we conclude that the zone of immature cartilage cells belongs to the perichondrium, which thus contains two layers, an outer fibrous layer and an inner transitional layer of immature cartilage cells. Our conclusions are as follows: 1. Tracheal adventitia is divided into two layers, an outer loose and an inner dense fibrous layer. 2. Tracheal perichondrium also consists of two layers, an outer fibrous layer and an inner transitional layer. 3. The fibrous bundle originating from the adventitia joins the connective tissue of the annular ligement, probably in order to allow the trachea to stretch and bend.

Key words : tracheal adventitia, perichondrium, annular ligament, collagen, histology

J Otolaryngol Jpn $100:$ 1394-1400, 1997 